\title{
Egészségmǘveltséget mérő kérdőívek validálása hazai felnőttmintán
}

\author{
Mátyás Gabriella ${ }^{1,2}$ - Vincze Ferenc ${ }^{1}$ - Bíró Éva dr. ${ }^{1}$ \\ ${ }^{1}$ Debreceni Egyetem, Általános Orvostudományi Kar, Népegészség- és Járványtani Intézet, Debrecen \\ ${ }^{2}$ Debreceni Egyetem, Egészségtudományok Doktori Iskola, Debrecen
}

Bevezetés: Az eredményes gyógyítás, rehabilitáció, egészségre nevelés és egészségfejlesztés elengedhetetlen feltétele, hogy az egyén az egészségmúveltségének megfelelő módon jusson hozzá az egészségével kapcsolatos információkhoz.

Célkitüzés: A kutatás célja két, az egészségmúveltséget objektíven (Newest Vital Sign) és szubjektíven (Brief Health Literacy Screening Tool) mérő skála validálása volt. Ezen nemzetközi felmérésekben elterjedt és önmagukban is alkalmazható rövid tesztek segítségével vizsgálható az általános populáció egészségmưveltsége.

Módszer: A skálák tesztelése országos keresztmetszeti vizsgálat keretében zajlott a felnőtt lakosság körében. A kérdo"ívek megbízhatóságát és validitását az egyes kérdőíveken belüli Cronbach- $\alpha$, Spearman-Brown és korrigált item-totál korrelációs együtthatók, valamint feltáró faktorelemzés (főkomponens-elemzés, varimax rotáció) segítségével értékeltük.

Eredmények: A kérdőívek belső konzisztenciáját mérő Cronbach- $\alpha$-érték a Newest Vital Sign kérdőív esetében 0,72, a Brief Health Literacy Screening Tool kérdőív esetében 0,87, míg a Spearman-Brown-féle korrigált korrelációval számított „split-half” megbízhatóság 0,76, illetve 0,88 volt. Az item-totál korrelációs vizsgálat során kapott korrelációs együtthatók minden esetben magasabbnak bizonyultak az elvárható 0,3-as értéknél. A faktorszerkezet feltárása rávilágított, hogy a két teszt az egészségmúveltség más-más dimenzióit méri.

Megbeszélés: Eredményeink alapján mindkét teszt megbízhatónak bizonyult; a Brief Health Literacy Screening Tool skála belső validitása magasabb, mint az eredeti kérdőívé. A faktorelemzés alapján a két kérdőív együttes alkalmazása is lehetséges, ha a cél a szubjektív és az objektív mưveltség egyszerre történő vizsgálata.

Következtetés: Eredményeink alapján javasoljuk a Brief Health Literacy Screening Tool és a Newest Vital Sign kérdőívek általunk validált változatának használatát kérdezőbiztosok által felvett, egészségmúveltséget vizsgáló felmérések részeként.

Orv Hetil. 2021; 162(39): 1579-1588.

Kulcsszavak: felmérések és kérdőívek, egészségmúveltség, validálási tanulmányok

\section{Validation of health literacy questionnaires in Hungarian adult sample}

Introduction: Accessing health information adapted to one's health literacy level is a prerequisite for effective healing, rehabilitation, health education, and health promotion.

Objective: This research aimed to validate the Hungarian version of two instruments measuring health literacy: the performance-based Newest Vital Sign and the self-reported Brief Health Literacy Screening Tool. These short instruments, which are frequently used in international surveys, can be applied to measure health literacy among the general population.

Method: The two instruments were tested in a nationwide cross-sectional study in the general population. The questionnaires' reliability and validity were evaluated using Cronbach- $\alpha$, Spearman-Brown, corrected item-total correlation coefficients, and exploratory factor analysis (principal components analysis, varimax rotation).

Results: The internal consistency measured by the Cronbach- $\alpha$ was 0.72 for the Newest Vital Sign and 0.87 for the Brief Health Literacy Screening Tool, and the split-half reliabilities calculated with the Spearman-Brown correlation were 0.76 and 0.88 , respectively. The correlation coefficients obtained during the item-total correlation analysis proved to be higher than the expected 0.3 value in all cases. Exploring the factor structure revealed that the two tests measure different dimensions of health literacy.

Discussion: Both tests proved to be reliable; the internal validity of the Brief Health Literacy Screening Tool is higher than that of the original questionnaire. Based on the factor analysis, their application is possible together if the goal is to examine subjective and objective health literacy together.

Conclusion: Using the validated Hungarian version of these questionnaires is recommended as part of health literacy surveys conducted by interviewers. 
Keywords: surveys and questionnaires, health literacy, validation studies

Mátyás G, Vincze F, Bíró É. [Validation of health literacy questionnaires in Hungarian adult sample]. Orv Hetil. 2021; 162(39): 1579-1588.

(Beérkezett: 2021. február 13.; elfogadva: 2021. március 15.)

\begin{abstract}
Rövidítések
BRIEF $=($ Brief Health Literacy Screening Tool $)$ Rövid Egészségmúveltségi Szúrő Teszt; ELEF = Európai Lakossági Egészségfelmérés; EU = Európai Unió; HLS-EU = (European Health Literacy Survey) Európai Egészségműveltség Felmérés; IKT = interkvartilis távolság; NVS = (Newest Vital Sign $)$ a funkcionális egészségmúveltséget vizsgáló teszt; S-TOFHLA = (Short-Test of Functional Health Literacy in Adults) Rövid Felnőtt Funkcionális Egészségműveltség Teszt; WHO = (World Health Organization) Egészségügyi Világszervezet
\end{abstract}

Az eredményes gyógyítás, rehabilitáció, egészségre nevelés és egészségfejlesztés elengedhetetlen feltétele, hogy az egyén egészségműveltségének (health literacy) megfelelő módon közöljük, tegyük elérhetővé számára az egészségével kapcsolatos információkat. Az adekvát egészségmúveltség elősegíti az egészséges életmód kialakítását és fenntartását, valamint az egészséget érintő ügyekben történő informált döntéshozatalt. A megfelelő szintű egészségmúveltség ugyancsak segíti az egyént abban, hogy eligazodjék az egészségügyi ellátórendszerben, annak szolgáltatásait is megfelelő mértékben használja. A nem megfelelő egészségmúveltségű egyének egészségi mutatói rosszabbak, kevésbé veszik igénybe a prevenciós szolgáltatásokat. Emiatt gyakrabban keresik fel a sürgősségi betegellátást, illetve szorulnak kórházi ellátásra, és kevésbé valószínú, hogy megfelelő módon hajtják végre az orvosnak a gyógyszerszedésre vonatkozó utasításait [1].

A nem megfelelő szintű egészségmúveltség nemzetgazdasági szinten is komoly anyagi vonzattal jár: egy becslés szerint az Amerikai Egyesült Államokban ez évi 106-238 milliárd dolláros többletkiadást jelent, hozzávetőlegesen az egészségügyi kiadások 7-17\%-át [2]. Feltételezhető, hogy az alacsonyabb egészségmúveltséggel jellemezhető egyének hazánkban is többletterhet rónak az egészségügyi ellátórendszerre.

Az egészségműveltség mint kifejezés először 1974ben látott napvilágot. Simonds, aki az oktatásról szóló esszéjében bevezette a fogalmat, arról beszélt, hogy tanulmányaik során a diákoknak az egészség terén is ugyanúgy szövegértővé és írástudóvá kell válniuk, képesnek kell lenniük egyes ismeretek megszerzésére, mint a többi tantárgy esetében [3].

Az egészségmúveltségnek számos definíciója létezik, első említése óta jelentős átalakuláson ment keresztül. Az egyik leggyakrabban használt meghatározása a WHO
1998. évi definíciója, mely szerint az egészségműveltség „az emberek kognitív és szociális készsége; meghatározza az egyének motivációját és az egyének képességét, amelynek segítségével hozzáférnek, megértik és felhasználják az egészségüket elősegítő és fenntartó információkat" $[4,5]$.

Egy 2012-ben megjelent szisztematikus áttekintő tanulmány az egészségműveltség 17-féle definícióját vette számba, majd a szerzők ezek alapján alkották meg az egészségmúveltség integrált modelljét. Sørensen és mtsai szerint azért volt szükség az integrált modell létrehozására, mert az egészségmúveltség korábbi koncepcióiban nem vették kellőképpen figyelembe annak folyamatjellegét. Az integrált modell ezen túl nemcsak az egyéni szintet veszi figyelembe, hanem az egészségműveltségre ható társadalmi és környezeti tényezőket is. Az integrált modell szerint „az egészségmúveltség kapcsolatban áll a múveltséggel, és hozzájárul ahhoz, hogy az emberek tudása, motivációja és kompetenciája alkalmassá váljon az egészséginformációkhoz való hozzáféréshez, azok megértéséhez, értékeléséhez és alkalmazásukhoz a mindennapi életben bekövetkező véleményalkotás és döntéshozatal idején az egészségügyi ellátás, a prevenció és az egészségfejlesztés területén, annak érdekében, hogy fenntartsuk vagy javítsuk az életminőséget életünk során” $[4,6]$.

$\mathrm{Az}$ egészségmúveltség mérésére számos validált teszt áll rendelkezésre, melyek mérni képesek az egészségmüveltség különböző aspektusait, szintjét, illetve specifikus területeit. Egy szisztematikus áttekintő tanulmány összesen 51 mérőeszközt vett számba, melyek közül 26 skála használható az általános populáció egészségműveltségének felmérésére. Ezen skálák egy része önmegítélés alapján (szubjektív), másik része pedig a helyes válaszok alapján (objektív) méri az egészségmúveltség szintjét [7].

\section{Magyarországi vizsgálatok az általános populációban}

Papp-Zipernovszky és mtsai 2015-ben 302 fós mintán mérték fel a lakosság egészségmúveltségét. Vizsgálatukban a mintavétel két hullámban történt: előbb kényelmi mintavétellel, majd pedig célzottan, hogy nem, életkor és iskolai végzettség szerint reprezentatív minta álljon rendelkezésükre. A felmérés során az S-TOFHLA és a Chew-teszt magyar validálását végezték el. Vizsgálatuk szerint az S-TOFHLA-kérdőív szövegértést mérő része 
alapján a résztvevők 86\%-ának megfelelő mértékű az egészségmúveltsége, 8\%-nak inadekvát, 6\%-nak pedig korlátozott. Az S-TOFHLA-kérdőív részeinek belsőkonzisztencia-mutatói heterogén képet adtak, a szövegértés Cronbach- $\alpha$-értéke 0,955 volt, viszont a számolási rész alacsony megbízhatóságot jelzett (Cronbach- $\alpha$ : 0,392) [8, 9]. A Chew-teszt validált változatának Cronbach- $\alpha$-értéke elfogadható megbízhatóságúnak adódott $(0,648)$.

Ugyancsak 2015-ben mérte fel Koltai és Kun 1008 fős, reprezentatív lakossági mintán az objektív és a szubjektív egészségmúveltség szintjét $[10,11]$. Vizsgálatukhoz a nyolc országra kiterjedő, 2011. évi HLS-EU felmérés kérdőívét, illetve a hazai mintán korábban még nem validált NVS-skálát használták. Eredményeik szerint a vizsgálatba bevontak 12\%-ának nagy valószínúséggel korlátozott, 20\%-nak valószínúleg korlátozott, 68\%-nak pedig nagy valószínúséggel megfelelő a funkcionális egészségmúveltsége (azaz az egészségtárgyú szövegértése). Ez európai összehasonlításban kifejezetten jó eredménynek minősül, ennél jobb eredményt mindössze Hollandiában értek el a válaszadók, ahol 76\%-nak volt nagy valószínüséggel megfelelő a funkcionális egészségmûveltsége, európai szinten pedig a mintába bevontak 55\%-a helyezkedik el ezen a nívón [10]. A szubjektív egészségmúveltség eredményei ezzel szemben nem voltak ennyire kiemelkedőek. Az összesített egészségértési index szerint hazánkban a szubjektív egészségmúveltség korlátozottnak tekinthető, a lakosság 52\%-a tartozott az elégtelen vagy problémás kategóriába, ami meghaladja az európai átlagot $(47 \%)$ [11].

Mivel eddig Magyarországon csak kevés validált mérőeszköz publikálása történt meg [8-10], kutatásunk célja két, az egészségmûveltséget különböző aspektusból mérő kérdőív magyar nyelvű változatának validálása volt. A validálni kívánt mérôeszközök kiválasztása két kritérium mentén történt: 1) az általános populációban történő használatuk nemzetközi felmérésekben elterjedt legyen, 2) olyan, önmagukban is használható, rövid tesztek legyenek, melyeket egy komplex, az egészségmúveltség különböző dimenzióit objektív és szubjektív szempontból vizsgáló kérdőív összeállításakor is alkalmazni lehet. Ezen szempontok alapján került kiválasztásra a BRIEF és az NVS; ugyan ez utóbbit hazai felmérésekben már használták [10], de ismereteink szerint a kérdőív hazai viszonyokra történő adaptálása még nem történt meg, illetve a magyar változatot sem közölték.

\section{Módszer}

\section{A validálandó kérdöípek bemutatása}

\section{BRIEF (Brief Health Literacy Screening Tool)}

A 2006-ban kialakított, szabadon használható BRIEFskála négy kérdésből áll, melyet általában önkitöltős módon vesznek fel. Ez az eszköz az egészségműveltséget szubjektíven méri. A négyből három elem a Chew-kér- dőívnek [12] feleltethető meg, az utolsó kérdés pedig a verbális információk megértésére vonatkozik [13]. Kevesebb mint 2 perc alatt kitölthető [12]. Az eredeti mérőeszköz validált, belsőkonzisztencia-értéke megfelelönek (Cronbach- $\alpha$ : 0,77) minősült [14]. Az ötfokú Likert-skálán (1-5) adott válaszok összegzésével kerül meghatározásra az összpontszám (4-20 pont), mely alapján az alábbi kategóriák alakíthatók ki: inadekvát (4-12), marginális (13-16) és adekvát (17-20) egészségmúveltség [13].

\section{NVS (Newest Vital Sign)}

A 2005-ben Weiss és mtsai [15] által kifejlesztett és validált kérdőívet egy közelmúltban megjelent áttekintő cikk a legpraktikusabb egészségmúveltséget mérő eszközként értékelte [16]. Az NVS a funkcionális egészségmúveltséget objektíven méri egészségi tárgyú szövegértés és számolási készségek alapján. Az adatfelvétel kérdezóbiztos által történik, irodalmi adatok alapján kitöltési ideje átlagosan 3 perc (1,5-6 perc között) [15]. A vizsgálati személynek egy jégkrémesdoboz tápanyagcímkéje alapján kell megválaszolnia hat kérdést. Több nyelven is elérhető, a különböző változatokban a tápanyag-információk megjelenítését igazították a lokális viszonyokhoz [17-18]. Korábbi kutatásokban a Cronbach- $\alpha$ értéke megfelelő volt, 0,74 és 0,76 között variálódott $[15,17]$. Minden helyesen megválaszolt kérdésre 1 pontot lehet kapni, majd ezek összegzése (0-6 pont) alapján a válaszadók három kategóriába sorolhatók: nagy valószínúséggel inadekvát (0-1 pont), valószínúleg limitált (2-3 pont) és nagy valószínúséggel megfelelő (4-6 pont) egészségmúveltségi szinttel rendelkezők [15].

\section{A kérdöinek magyar változatának elkészitése}

Két független szakértő végezte az eredeti, angol nyelvű kérdőívek előbb magyar nyelvre, majd vissza angol nyelvre történő fordítását. Orvos- és egészségtudományi szakfordítót kértünk meg a fordítás ellenőrzésére és az eredeti változattal való összehasonlításra.

Az NVS magyar nyelvú változatának elkészítése az eredeti kérdőívet kidolgozók ${ }^{1}$ engedélyével történt. Ennek kialakításakor, beleértve a kérdezőbiztosi instrukciókat is, támaszkodtunk a kérdőívnek a 2015. évi országos felmérés [10] során használt, nem publikált változatára, valamint a kérdőív eredeti változatának kidolgozója által írt tanácsokat is figyelembe vettük [18]. A tápanyagcímkét adaptáltuk a hazai viszonyokhoz, figyelembe véve az Európai Parlament és a Tanács 1169/2011/EU rendeletét a fogyasztók élelmiszerekkel kapcsolatos tájékoztatásáról. Az így elkészült változat véleményezése két, egy-

A kérdőív a klinikumban és kutatási célokra szabadon felhasználható, de módosítása, beleértve a fordítást is, engedélyhez kötött, mely a Pfizer Inc.-től kérhető: Newest Vital Sign (NVS) Toolkit https://www.pfizerpcoa.com/newestvital-sign-nvs-toolkit-screener 
l. kérdőív $\quad$ A Brief Health Literacy Screening Tool (BRIEF) magyar változata

Az alábbiakban arra vagyunk kíváncsiak, hogy mennyire okoz Önnek nehézséget az egészségével kapcsolatban informálódni. Kérjük, jelölje meg az Önre legjellemzőbb választ.

1. Milyen gyakran van szüksége Önnek segítségre az írott egészségügyi dokumentumok (például ambulánslap, zárójelentés, beleegyező nyilatkozat) értelmezéséhez?

Pontositás a kérdezönek: Az orvos által irt dokumentumokra vonatkozik a kérdés. Ha a válaszadó nem szokott orvoshoz járni, vagy nem olvassa el a kapott dokumentációt, jelölje a 'nem tudom' választ.
1. mindig
2. gyakran
3. néha
4. nagyon ritkán
5. soha
0. nem tudom

2. Az egészségi állapotáról való tájékozódás során milyen gyakran okoz nehézséget Önnek a betegtájékoztató anyagok, szórólapok megértése?

Pontositás a kérdezönek: A laikusoknak, nem szakembereknek szóló tájékoztatókra vonatkozik a kérdés. Ha a válaszadó nem szokott ilyeneket olvasni, jelölje a 'nem tudom' választ.
1. mindig
2. gyakran
3. néha
4. nagyon ritkán
5. soha
0. nem tudom

3. Milyen gyakran okoz problémát annak megértése, amit az egészségi állapotáról mondanak Önnek?

Pontositás a kérdezőnek: Az orvos, gyógyszerész, más egészségügyi dolgozó (például ápolónő, védőnö, gyógytornász) által szóban elmondott információkra vonatkozik a kérdés. Ha a válaszadó nem szokott orvoshoz vagy gyógyszertárba járni, jelölje a 'nem tudom' választ.
1. mindig
2. gyakran
3. néha
4. nagyon ritkán
5. soha
0. nem tudom

4. Mennyire érzi magabiztosnak magát, amikor önállóan tölt ki az egészségi állapotával kapcsolatos ürlapokat? Pontositás a kérdezönek: Olyan helyzetekre gondoljon, amikor a saját egészségi állapotára vonatkozóan kell irásban információkat megadni (például magánrendelésen, biztositás kötésekor, különféle egészségügyi szolgáltatások igénybevételekor). Ha a válaszadó nem töltött ki még ilyet, jelölje a 'nem tudom' választ
1. egyáltán nem
2. kevéssé
3. valamennyire
4. eléggé
5. nagyon
0. nem tudom

mástól független táplálkozástudományi szakember segítségével történt. Az ő visszajelzéseik alapján véglegesítettük a tápanyagcímkét, amely nemcsak a kérdések megválaszolásához szükséges információkat tartalmazza, hanem tartalmában és formájában is összehangolásra került az üzletekben elérhető termékeken megtalálható tápanyagcímkékkel. Az eredeti változatban a kérdezőbiztosnál megvoltak a jó válaszok, de felmerült egy előző magyarországi kutatás során, hogy ez torzíthatja az eredményeket [10], így vizsgálatunkban nyitott kérdéseket használtunk, és csak az adatbevitel során kerültek kódolásra a válaszok.

\section{Vizsgálati minta és adatgyüjtés}

A fentebb ismertetett módon kialakított magyar nyelvú változatok tesztelése - a jelen közlemény keretein belül nem részletezett - 18 év felettiek körében kivitelezett pilotvizsgálat keretében zajlott. Ezen szakértői mintán alapuló visszajelzések és a tapasztalatok alapján került sor a kérdőívek szövegének véglegesítésére (1. és 2. kérdöív).

A validálás következő lépéseként országos keresztmetszeti adatgyüjtést végeztünk a 18 éves és idősebb korosztály körében $(\mathrm{n}=1200)$. Az adatok gyújtését a Medián Közvélemény- és Piackutató Intézet végezte személyes kikérdezés segítségével. Az adatgyưjtés során használt kérdőív két részből tevődött össze. Az első rész a válaszadók szociodemográfiai adatait (nem, életkor, iskolai végzettség, gazdasági aktivitás, önértékelt anyagi helyzet) mérte fel, a kérdőív második részében a BRIEF és NVS kérdőívek magyar nyelvü változatai szerepeltek.

\section{Statisztikai elemzés}

$\mathrm{Az}$ adatelemzés során a válaszadókat az életkor alapján három kategóriába soroltuk be (18-34, 35-64, 65 éves vagy idősebb). Az iskolai végzettség tekintetében 8 osztályos végzettség, szakmunkásképzői végzettség, középiskola érettségivel és főiskola/egyetem diplomával kategóriákat alakítottunk ki. A gazdasági aktivitás felmérésére az ELEF-ekben használt standardizált kategóriákat alkalmaztuk. Az egyes kategóriákra adott alacsony válaszadási gyakoriságok miatt az alábbi összevont kategóriákkal dolgoztunk: aktív, nyugdíjas, inaktív, tanuló. A szocioökonómiai státusz szubjektív felmérésére az alábbi kérdést alkalmaztuk: „Milyennek ítéli az Önök anyagi helyzetét?". A válaszokat ötfokú Likert-skálán értékeltük a nagyon jó (1) és a nagyon rossz (5) végpontok között; a válaszokat 'rossz', 'megfelelő' és 'jó' kategóriák kialakítását követően elemeztük. 


\section{\begin{tabular}{l|l} 
2. kérdőiv & A Newest Vital Sign (NVS) magyar változata2,3
\end{tabular}}

Kérjük, hogy az itt található tápanyagcímke alapján válaszolja meg az alábbi kérdéseket.

\begin{tabular}{|c|c|c|c|}
\hline \multicolumn{4}{|c|}{$\begin{array}{l}\text { Vaníliaízú jégkrém } \\
\text { Összetevők: tejszín, sovány tej, folyékony cukor, víz, tojássárgája, barna cukor, tejzsír, földimogyoró-olaj, cukor, vaj, } \\
\text { só, karragén, vaníliakivonat. }\end{array}$} \\
\hline \multicolumn{4}{|l|}{ Átlagos tápértéktartalom } \\
\hline & $100 \mathrm{~g}$ termékben & 1 adagban $(100 \mathrm{ml})^{*}$ & RBÉ\% (1 adagra)* * \\
\hline Energia & $313 \mathrm{kcal} / 1313 \mathrm{~kJ}$ & $250 \mathrm{kcal} / 1050 \mathrm{~kJ}$ & $13 \%$ \\
\hline Zsír & $16 \mathrm{~g}$ & $13 \mathrm{~g}$ & $19 \%$ \\
\hline amelyből telített zsírsavak & $11 \mathrm{~g}$ & $9 \mathrm{~g}$ & $45 \%$ \\
\hline Szénhidrát & $38 \mathrm{~g}$ & $30 \mathrm{~g}$ & $12 \%$ \\
\hline amelyből cukrok & $29 \mathrm{~g}$ & $23 \mathrm{~g}$ & $26 \%$ \\
\hline Rost & $2,5 \mathrm{~g}$ & $2 \mathrm{~g}$ & \\
\hline Fehérje & $5 \mathrm{~g}$ & $4 \mathrm{~g}$ & $8 \%$ \\
\hline Só & $0,18 \mathrm{~g}$ & $0,14 \mathrm{~g}$ & $2 \%$ \\
\hline
\end{tabular}

1. Ha megeszik ebből a jégkrémből egy egész dobozzal, mennyi kalóriát (kcal-ban megadva) fogyaszt el?

2. Ha 60 g szénhidrátot fogyaszthat édesség gyanánt, mennyit ehet ebből a jégkrémből?

3. Orvosa azt tanácsolja, hogy csökkentse a telített zsírok fogyasztását. Általában $42 \mathrm{~g}$ telített zsírt fogyaszt naponta, amelyben benne van egy adag jégkrém elfogyasztása. Ha nem enne jégkrémet, hány gramm telített zsírt fogyasztana egy nap?

4. Ha naponta átlagosan 2500 kalóriát (kcal-ban mérve) eszik, akkor egy adag jégkrém elfogyasztása ennek hány százalékát teszi ki?

5. Feltételezzük azt, hogy allergiás a következőkre: penicillin, földimogyoró, latex, méhcsípés. Biztonságos ennie ebből a jégkrémből?

6. Miért? (Indokolja meg az elöző kérdésre adott válaszát.)

${ }^{2}$ A skála felvételéhez szükséges instrukciókat a szerzők az érdeklődóknek készséggel rendelkezésükre bocsátják. Segítség az értékeléshez: https://healthliteracy.bu.edu/documents $/ 21 / 2 \% 20-\% 20$ Newest $\% 20$ Vital $\% 20$ Sign $\% 20$ Score $\% 20$ Sheet $\% 20$ English.pdf

${ }^{3}$ További információ a kitöltéshez kapcsolódóan esetleges felmerülő kérdések megválaszolásához: Weiss BD. The Newest Vital Sign: frequently asked questions. Health Lit Res Pract. 2018; 2: e125-e127. Doi: 10.3928/24748307-20180530-02

Az adatfeldolgozás során a mérőeszközök megbízhatóságát (reliabilitás) és validitását IBM SPSS 26.0 programcsomag (IBM Corp. released 2019. IBM SPSS Statistics for Windows, Armonk, NY, Amerikai Egyesült Államok) használatával elemeztük. A válaszadók szociodemográfiai összetételét esetszámok és százalékos megoszlások (\%) segítségével jellemeztük. Az NVS és BRIEF kérdőívekre adott válaszok megoszlását középérték (medián) és szóródás (IKT) mutatók segítségével határoztuk meg.

A kérdőívek belső konzisztenciáját (internal consistency) Cronbach- $\alpha$ és Spearman-Brown korrelációs együtthatók segítségével értékeltük. A belső konzisztenciát számszerúsítő Cronbach- $\alpha$ értékét 0,70 és 0,95 között tekintettük elfogadhatónak [19]. A kérdőívek megismételt adatfelvételére („test-retest” elemzés) nem volt lehetőség, ezért a „split-half” módszer segítségével alternatív reliabilitási mutató került számszerüsítésre. A mód- szer lényege, hogy kérdőívenként az alskálákat véletlenszerüen kettévágjuk két csoportba, a részekre adható pontértékeket összegezzük, és kérdőívenként korrigált Spearman-Brown korrelációs együtthatók segítségével vizsgáljuk a kettévágott skálák összpontszámai közötti korrelációt [20]. Az alábbi határértékeket vettük alapul a korrelációs együtthatók értelmezése során: 0,5-0,7: közepes; 0,7-0,9: erôs; 0,9: nagyon erôs [21]. A kérdőívek szenzitivitási vizsgálata során a belső konzisztencia mutatókat a szociodemográfiai változók alapján képzett alminták esetében is kiszámítottuk (leszámítva a tanulók almintáját, amelynél az alacsony esetszámok miatt nem volt lehetőség az elemzések elvégzésére).

A kérdőívek megbízhatóságának értékelése során elemeztük továbbá a kérdőívek alskáláin mérhető pontszámok és a teljes kérdőívek között lévő megbízhatóságot korrigált item-totál korrelációs vizsgálattal [22]. A mutató értékelése során 0,30 vagy magasabb értéket tekintet- 
tünk megfelelőnek. Vizsgáltuk továbbá a Cronbach- $\alpha$ értékének változását az egyes kérdőívtételek törlését követően.

A kérdőívek validitását a konstrukciós érvényességen (construction validity) keresztül feltáró faktorelemzés (főkomponens-elemzés, varimax rotáció) segítségével írtuk le. A kérdőívtételek szelekciója során alkalmazott, minimálisan elvárható kommunalitási érték 0,20 volt [23]. A konstrukciós validitás elemzése során arra kerestük a választ, hogy az adott skálák egyes tételei mennyire fogták át a mérendő fogalom jelentéstartományát (az itemek valóban azt mérték-e, amit mérni szerettünk volna).

\section{Eredmények}

\section{A vizsgálati populáció jellemzése}

Az adatelemzés során a bármely változó vonatkozásában hiányzó válaszokkal rendelkező személyeket kizártuk a további adatfeldolgozásból, így az elemzés alapját 824 fós adatbázis képviselte. A mintában női túlsúly volt megfigyelhető $(60,68 \%)$. A 35-64 éves korcsoportba tartozók aránya 60,32\%-nak adódott, a 65 évesek vagy idősebbek részaránya $26,58 \%$ volt. A válaszadók megközelítőleg háromnegyede szakmunkásképzői (37,01\%) vagy középiskolai $(36,89 \%)$ végzettséggel rendelkezett. A gazdasági aktivitás tekintetében a megkérdezettek több mint fele, 58,01\%-a volt aktív dolgozó. Szocioökonómiai státusz szubjektív megítélésekor 156 fó (18,93\%) rossznak, 460 fó $(55,82 \%)$ megfelelőnek, 208 fó $(25,24 \%)$ jónak ítélte meg anyagi helyzetét (1. táblázat).

1. táblázat | A vizsgált minta megoszlása a szociodemográfiai változók alapján

\begin{tabular}{|c|c|c|}
\hline & & Esetszám (\%) \\
\hline \multirow[t]{2}{*}{ Nem } & Férfi & $324(39,32)$ \\
\hline & Nő & $500(60,68)$ \\
\hline \multirow[t]{3}{*}{ Életkor } & 18-34 éves & $108(13,11)$ \\
\hline & 35-64 éves & $497(60,32)$ \\
\hline & 65 éves vagy idősebb & $219(26,58)$ \\
\hline \multirow{4}{*}{$\begin{array}{l}\text { Iskolai } \\
\text { végzettség }\end{array}$} & 8 osztály & $106(12,86)$ \\
\hline & Szakmunkásképző & $305(37,01)$ \\
\hline & Középiskola érettségivel & $304(36,89)$ \\
\hline & Főiskola vagy egyetem diplomával & $109(13,23)$ \\
\hline \multirow{4}{*}{$\begin{array}{l}\text { Gazdasági } \\
\text { aktivitás }\end{array}$} & Aktív & $478(58,01)$ \\
\hline & Nyugdíjas & $282(34,22)$ \\
\hline & Inaktív & $57(6,92)$ \\
\hline & Tanuló & $7(0,85)$ \\
\hline \multirow{3}{*}{$\begin{array}{l}\text { Önértékelt } \\
\text { anyagi helyzet }\end{array}$} & Rossz & $156(18,93)$ \\
\hline & Megfelelő & $460(55,82)$ \\
\hline & Jó & $208(25,24)$ \\
\hline Összesen & & $824(100,00)$ \\
\hline
\end{tabular}

Az NVS-kérdőív medián összesített pontértéke 4 (IKT: 2), míg a BRIEF összesített medián pontértéke 15 (IKT: 6) volt.

\section{A kérdoívek megbizhatósága}

A vizsgált minta és az elemzett alminták esetében a kérdőívek belső konzisztenciáját mérő Cronbach- $\alpha$ értékei minden esetben meghaladták a minimálisan elvárható 0,70-es értéket (2. táblázat). A konzisztencia-mérőszám a teljes minta esetében 0,72-es értéket mutatott az NVSkérdőív és 0,87-es értéket a BRIEF-kérdőív esetében. Az alminták esetében az NVS-kérdőív Cronbach- $\alpha$-értéke 0,70 és 0,75 között variálódott. A legalacsonyabb értékeket a nők, a 8 osztályos iskolai végzettséggel rendelkezők, illetve a fóiskolai vagy egyetemi végzettséggel rendelkezők körében lehetett látni. Az NVS-kérdőív belső konzisztenciája a férfiak körében végzett almintás elemzések esetében bizonyult a legmagasabbnak $(0,75)$. A BRIEFkérdőív almintákon számszerúsített Cronbach- $\alpha$-értékei 0,84 és 0,89 között alakultak. A legalacsonyabb konzisztenciaértéket $(0,84)$ a megfelelő önértékelt vagyoni helyzettel rendelkezők és a középiskolai végzettségűek almintájában lehetett látni. A jó önértékelt vagyoni helyzetú válaszadók almintájában bizonyult a BRIEF-kérdőív belső konzisztencia mutatója a legmagasabbnak $(0,89)$.

Az NVS-kérdóív Spearman-Brown-féle korrigált korrelációval számított „split-half” megbízhatósága 0,76nak adódott; a koefficiensek az alminták esetében 0,71 és 0,78 között variálódtak. Az NVS-kérdőív esetében a legalacsonyabb együtthatót a jó önértékelt vagyoni helyzetű válaszadók almintáján lehetett mérni. Az NVS Spearman-Brown-féle „split-half” megbízhatósága a fóiskolai vagy egyetemi végzettségú, a gazdaságilag inaktív, a rossz önértékelt vagyoni helyzetű válaszadók almintájában adódott a legmagasabbnak $(0,78)$. A BRIEF-kérdóív teljes mintán mért „split-half” megbízhatósága 0,88 volt, mely az alminták esetében 0,86-os és 0,91-es értékek között szóródott. Az alminták esetében a legalacsonyabb együtthatót a középiskolai végzettségúek almintáján mértük, míg a legmagasabb értékekkel a gazdaságilag inaktívak almintája volt jellemezhető (2. táblázat).

Az item-totál korrelációs vizsgálat során kapott korrelációs együtthatók minden esetben magasabbnak bizonyultak az elvárható 0,3-as értéknél, ami az egyes itemek megfelelő korreláltságát jelezte a kérdőívek egészéhez képest. Az NVS esetében a legalacsonyabb értéket $(\mathrm{r}=$ 0,33) a „Feltételezzük azt, hogy allergiás a következőkre: penicillin, földimogyoró, latex, méhcsípés. Biztonságos ennie ebből a jégkrémből?" kérdés esetében kaptuk, míg a legerôsebb korrelációs együtthatót $(\mathrm{r}=0,54)$ a „Ha naponta átlagosan 2500 kalóriát (kcal-ban mérve) eszik, akkor egy adag jégkrém elfogyasztása ennek hány százalékát teszi ki?" kérdés esetében lehetett számszerüsíteni. Az item-totál korrelációs együtthatók minimuma a BRIEF-kérdőív esetében 0,53-nak („Mennyire érzi magabiztosnak magát, amikor önállóan tölt ki az egész- 
2. táblázat |Az NVS és BRIEF kérdő́vek konzisztencia- és reprodukálhatósági mutatói a teljes mintán és az almintákon végzett elemzések alapján

\begin{tabular}{|c|c|c|c|c|}
\hline & & & NVS & BRIEF \\
\hline \multirow[t]{2}{*}{ Teljes mint: } & & Cronbach- $\alpha$ & 0,72 & 0,87 \\
\hline & & Spearman-Brown-koefficiensek & 0,76 & 0,88 \\
\hline \multirow[t]{30}{*}{ Alminták } & \multirow[t]{2}{*}{ Férfiak } & Cronbach- $\alpha$ & 0,75 & 0,86 \\
\hline & & Spearman-Brown-koefficiensek & 0,76 & 0,87 \\
\hline & \multirow[t]{2}{*}{ Nők } & Cronbach- $\alpha$ & 0,70 & 0,87 \\
\hline & & Spearman-Brown-koefficiensek & 0,75 & 0,90 \\
\hline & \multirow[t]{2}{*}{ 18-34 évesek } & Cronbach- $\alpha$ & 0,74 & 0,85 \\
\hline & & Spearman-Brown-koefficiensek & 0,76 & 0,88 \\
\hline & \multirow[t]{2}{*}{ 35-64 évesek } & Cronbach- $\alpha$ & 0,72 & 0,86 \\
\hline & & Spearman-Brown-koefficiensek & 0,76 & 0,88 \\
\hline & \multirow[t]{2}{*}{65 évesek vagy idősebbek } & Cronbach- $\alpha$ & 0,71 & 0,88 \\
\hline & & Spearman-Brown-koefficiensek & 0,75 & 0,89 \\
\hline & \multirow[t]{2}{*}{8 osztályos iskolai végzettség } & Cronbach- $\alpha$ & 0,70 & 0,88 \\
\hline & & $\begin{array}{l}\text { Spearman-Brown-koefficiensek } \\
\text { nat }\end{array}$ & 0,75 & 0,90 \\
\hline & \multirow[t]{2}{*}{ Szakmunkásképzői iskolai végzettség } & Cronbach- $\alpha$ & 0,73 & 0,87 \\
\hline & & Spearman-Brown-koefficiensek & 0,75 & 0,89 \\
\hline & \multirow[t]{2}{*}{ Középiskolai végzettség érettségivel } & Cronbach- $\alpha$ & 0,72 & 0,84 \\
\hline & & Spearman-Brown-koefficiensek & 0,76 & 0,86 \\
\hline & \multirow{2}{*}{$\begin{array}{l}\text { Főiskolai vagy egyetemi végzettség } \\
\text { diplomával }\end{array}$} & Cronbach- $\alpha$ & 0,70 & 0,85 \\
\hline & & Spearman-Brown-koefficiensek & 0,78 & 0,89 \\
\hline & \multirow[t]{2}{*}{ Gazdasági aktivitás: aktív } & Cronbach- $\alpha$ & 0,73 & 0,85 \\
\hline & & Spearman-Brown-koefficiensek & 0,75 & 0,87 \\
\hline & \multirow[t]{2}{*}{ Gazdasági aktivitás: nyugdíjas } & Cronbach- $\alpha$ & 0,71 & 0,87 \\
\hline & & Spearman-Brown-koefficiensek & 0,76 & 0,89 \\
\hline & \multirow[t]{2}{*}{ Gazdasági aktivitás: inaktív } & Cronbach- $\alpha$ & 0,73 & 0,88 \\
\hline & & Spearman-Brown-koefficiensek & 0,78 & 0,91 \\
\hline & \multirow[t]{2}{*}{ Önértékelt vagyoni helyzet: rossz } & Cronbach- $\alpha$ & 0,74 & 0,87 \\
\hline & & Spearman-Brown-koefficiensek & 0,78 & 0,87 \\
\hline & \multirow{2}{*}{$\begin{array}{l}\text { Önértékelt vagyoni helyzet: } \\
\text { megfelelő }\end{array}$} & Cronbach- $\alpha$ & 0,72 & 0,84 \\
\hline & & Spearman-Brown-koefficiensek & 0,77 & 0,87 \\
\hline & \multirow[t]{2}{*}{ Önértékelt vagyoni helyzet: jó } & Cronbach- $\alpha$ & 0,71 & 0,89 \\
\hline & & Spearman-Brown-koefficiensek & 0,71 & 0,90 \\
\hline
\end{tabular}

BRIEF $=$ Brief Health Literacy Screening Tool; NVS $=$ Newest Vital Sign

ségi állapotával kapcsolatos ûrlapokat?”), míg a maximuma 0,83-nak („Az egészségi állapotáról való tájékozódás során milyen gyakran okoz nehézséget Önnek a betegtájékoztató anyagok, szórólapok megértése?") adódott.

Az NVS-kérdő́iv esetében egyik tétel törlésekor sem javult volna a Cronbach- $\alpha$ értéke, ugyanakkor a BRIEFkérdőív esetében kismértékú javulást lehetett volna elérni a „Mennyire érzi magabiztosnak magát, amikor önállóan tölt ki az egészségi állapotával kapcsolatos úrlapokat?" kérdés törlését követően $\left(\right.$ Cronbach- $\alpha_{\text {totál }}=$ 0,87 , Cronbach- $\alpha_{\text {item nélkül }}=0,90$ ).

\section{A kérdöinek konstrukciós érvényessége}

A konstrukciós érvényesség vizsgálatakor alkalmazott faktorelemzés során kapott Bartlett-teszt-eredmény szignifikánsnak bizonyult $(\mathrm{p}<0,001)$, a Kaiser-Meyer-
Olkin-kritérium értéke pedig 0,790-nek adódott. Ennek értelmében a tételek között összefüggés mutatkozott, az adatstruktúra latens változók azonosítására alkalmasnak bizonyult. A legalacsonyabb kommunalitási érték 0,25nek adódott, mely elérte a 0,20 -as elvárható minimális szintet, ezért a faktorstruktúra kialakítása során változó szelekciót nem alkalmaztunk. A rotált faktormátrix a 10 tételből (NVS: 6 tétel, BRIEF: 4 tétel) a 3. táblázatban látható faktorstruktúrát mutatta. A 0,4-nél magasabb értékű faktorsúlyokat figyelembe véve a tételek két faktor köré rendeződtek, melyek az NVS és a BRIEF latens dimenzióit képviselték. A faktorelemzést követően a kialakított két faktor (NVS és BRIEF) együttes magyarázóereje 54,21\%-nak adódott, melyből a BRIEF-kérdő́iv $35,61 \%$-ot, az NVS pedig 18,60\%-ot magyarázott. A rotációt követően nem találtunk olyan itemet, mely mindkét faktorhoz kötődött volna egyszerre. 
3. táblázat |Az NVS és BRIEF kérdőívek feltáró faktorelemzésének eredménye (tömörítési módszer: fő́komponens-elemzés varimax rotációval)

\begin{tabular}{|c|c|c|c|c|}
\hline & & \multicolumn{2}{|c|}{ Faktorok } & \multirow[t]{2}{*}{ Kommunalitás } \\
\hline & & BRIEF & NVS & \\
\hline \multirow{6}{*}{$\begin{array}{l}\mathrm{Az} \\
\text { NVS-kérdő- } \\
\text { ív tételei }\end{array}$} & $\begin{array}{l}\text { Ha megeszik ebből a jégkrémból egy egész dobozzal, mennyi kalóriát (kcal-ban } \\
\text { megadva) fogyaszt el? }\end{array}$ & 0,08 & 0,67 & 0,46 \\
\hline & Ha 60 g szénhidrátot fogyaszthat édesség gyanánt, mennyit ehet ebből a jégkrémből? & 0,12 & 0,65 & 0,43 \\
\hline & $\begin{array}{l}\text { Orvosa azt tanácsolja, hogy csökkentse a telített zsírok fogyasztását. Általában } 42 \text { g } \\
\text { telített zsírt fogyaszt naponta, amelyben benne van egy adag jégkrém elfogyasztása. } \\
\text { Ha nem enne jégkrémet, hány gramm telített zsírt fogyasztana egy nap? }\end{array}$ & 0,13 & 0,66 & 0,45 \\
\hline & $\begin{array}{l}\text { Ha naponta átlagosan } 2500 \text { kalóriát (kcal-ban mérve) eszik, akkor egy adag jégkrém } \\
\text { elfogyasztása ennek hány százalékát teszi ki? }\end{array}$ & 0,15 & 0,71 & 0,53 \\
\hline & $\begin{array}{l}\text { Feltételezzük azt, hogy allergiás a következőkre: penicillin, földimogyoró, latex, } \\
\text { méhcsípés. Biztonságos ennie ebből a jégkrémból? }\end{array}$ & 0,04 & 0,50 & 0,25 \\
\hline & Ha nem biztonságos, miért? & 0,06 & 0,63 & 0,40 \\
\hline \multirow{6}{*}{$\begin{array}{l}\text { A BRIEF- } \\
\text { kérdóív } \\
\text { tételei }\end{array}$} & $\begin{array}{l}\text { Milyen gyakran van szüksége Önnek segítségre az írott egészségügyi dokumentumok } \\
\text { (például ambulánslap, zárójelentés, beleegyezó nyilatkozat) értelmezéséhez? }\end{array}$ & 0,85 & 0,08 & 0,74 \\
\hline & $\begin{array}{l}\text { Az egészségi állapotáról való tájékozódás során milyen gyakran okoz nehézséget } \\
\text { Önnek a betegtájékoztató anyagok, szórólapok megértése? }\end{array}$ & 0,90 & 0,20 & 0,86 \\
\hline & $\begin{array}{l}\text { Milyen gyakran okoz problémát annak megértése, amit az egészségi állapotáról } \\
\text { mondanak Önnek? }\end{array}$ & 0,88 & 0,20 & 0,82 \\
\hline & $\begin{array}{l}\text { Mennyire érzi magabiztosnak magát, amikor önállóan tölt ki az egészségi állapotával } \\
\text { kapcsolatos ûrlapokat? }\end{array}$ & 0,70 & 0,03 & 0,49 \\
\hline & Saját érték & 3,56 & 1,86 & \\
\hline & Magyarázott variancia (\%) & 35,61 & 18,60 & \\
\hline
\end{tabular}

Kaiser-Meyer-Olkin-kritérium: 0,790; Bartlett-teszt: p<0,001

BRIEF $=$ Brief Health Literacy Screening Tool; NVS = Newest Vital Sign

\section{Megbeszélés}

Kutatásunk két, az egészségmúveltség különböző dimenzióit objektív és szubjektív szempontból vizsgáló kérdő́ív magyar nyelvű változatának validálására irányult.

Az elvégzett elemzések alapján az NVS-skála megbízhatónak bizonyult. A Cronbach- $\alpha$ értéke a korábbi kutatásokban [15, 17, 24-29] általában kapott értékekhez $(0,67-0,76)$ hasonló volt, és konzisztens értéket (az értékek terjedelme 0,05 volt) mutatott az alminták esetében is, bár megjegyzendő, hogy alacsonyabb mintaelemszámmal végzett vizsgálatokban publikáltak már magasabb $(0,79-0,80)$ Cronbach- $\alpha$-értékeket is [3031]. Kisszámú vizsgálat irányult a kérdő́iv almintákon történő elemzésére, de a publikált eredmények összecsengenek saját megfigyeléseinkkel, az NVS-kérdőív a magasabb iskolai végzettségúek körében alacsonyabb Cronbach- $\alpha$-értékkel jellemezhető [27]. Az egyes tételek megfelelő korreláltsága a kérdő́ív egészéhez képest és az a tény, hogy egyik tétel törlése esetében sem javulna számottevően a Cronbach- $\alpha$ értéke, összecseng három, hasonló elemzési módszert alkalmazó kutatás eredményével [29-31].

A BRIEF-skála belső konzisztenciája megfelelő volt, a kapott Cronbach- $\alpha$-érték magasabb volt, mint az eredeti változat validálása során kapott érték [14]; az alminták esetében a Cronbach- $\alpha$ értéke minimális, 0,05-ös terjede- lemmel volt jellemezhető. A kedvezőbb mutatókhoz hozzájárulhatott, hogy a jelen cikkben nem részletezett pilotvizsgálat során szerzett tapasztalatok alapján az egyes kérdésekhez tartozó értelmező szövegeket szükség esetén kiegészítettük, az első kérdés szövegét módosítottuk.

A faktorelemzés során kapott eredményeket alapul véve elmondható, hogy a BRIEF és az NVS az egészségmúveltség más-más dimenzióit méri, ezért a két kérdő́iv együttes alkalmazása is lehetséges, ha a cél a szubjektív és az objektív egészségmúveltség egyszerre történő vizsgálata. Ezzel együtt ezek a rövid kérdőívek természetesen nem mérik fel az egészségmúveltség minden aspektusát. Az NVS-kérdőívben lévő kérdések relevánsak az egészségi tárgyú szövegértés szempontjából, míg a BRIEF-kérdőiv itemei szubjektív módon értékelik az egészségügyi ellátáshoz kapcsolódó nehézségeket és kihívásokat.

A vizsgálat korlátai közé tartozik, hogy a középkorosztályba tartozók felülreprezentáltak a mintában, ugyanakkor a tanulók alacsony számban kerültek bevonásra, így almintás elemzést körükben nem lehetett végezni. Ugyanakkor feltételezhetjük, hogy az iskolai végzettség erősebb determináns a foglalkoztatottsági státusznál, így ez vélhetően nem befolyásolja érdemben a kérdő́ivekkel kapcsolatos megállapításainkat. Különösen, hogy a validitási vizsgálatok során általában alkalmazott kisebb mintákhoz képest egy országos nagy mintán gyújtött adatokon történt meg a validitás értékelése. 
Az eredmények alapján az NVS és BRIEF skáláknak a jelen közleményben közölt változatát ajánljuk használni az egészségmúveltségi szint meghatározására kérdezőbiztos általi lekérdezést alkalmazó magyar nyelvű kutatásokban, célzott kisebb és nagy országos reprezentatív vizsgálatok alkalmával is. Ugyanakkor a vizsgált kérdőívek rövidsége miatt, amennyiben a kutatás középpontjában az egészségmúveltség részletesebb, több aspektusra kiterjedő vizsgálata áll, előfordulhat, hogy további kérdő́vek használata is szükséges. Azonban - különösen az NVS használata esetén - további elónnyel jár a nemzetközi kutatások eredményeivel való összehasonlítás lehetősége.

A kérdőívek magyar nyelvú validálását és a hazai gyakorlatban való alkalmazását azért tartjuk fontosnak, mert használatukkal lehetőség nyílik a nem kielégító egészségmúveltséggel rendelkező személyek azonosítására. Fontos megemlíteni, hogy a tesztek lényege nem a tudás mérése és osztályozása, hanem az egészségmúveltség szempontjából releváns készségek meglétének vizsgálata, a nehézségek feltérképezése. Mint korábban említettük, a nem megfelelő egészségmúveltségú egyének többletköltséget jelentenek az egészségügyi ellátórendszer számára, annak szolgáltatásait túl-, illetve alulhasználják, egészségi mutatóik rosszabbak. A mérőeszköz alkalmazásával, a kapott eredmények kiértékelését követően az egészségügyi témájú kommunikációt még differenciáltabbá lehet tenni, így nemcsak a népegészségügyi mutatókban érhetünk el javulást, hanem hosszabb távon akár nemzetgazdasági szinten. A tesztek eredményei felhasználhatók továbbá népegészségügyi programok tervezése és a kommunikáció hatékonyságának növelése során is.

Anyagi támogatás: A kutatást a GINOP-2.3.215-2016-00005 számú projekt támogatta. A projekt az Európai Unió támogatásával, az Európai Regionális Fejlesztési Alap társfinanszírozásával valósult meg.

Szerzói munkamegosztás: M. G. részt vett a kézirat megírásában. V. F. a Newest Vital Sign kérdőív tápanyagcímkéjének kialakításában és az adatelemzési terv készítésében részt vett, ő végezte az adatok elemzését és az ezzel kapcsolatos részek megírását. B. É. feladatai közé tartozott a kutatási koncepció kidolgozása, a kérdőívek kiválasztása, a skálák magyar nyelvú változatának véglegesítése, az adatfelvétel és az adatelemzés koordinálása és a kézirat szövegének javítása. A cikk végleges változatát valamennyi szerző elolvasta és jóváhagyta.

Érdekeltségek: A szerzőknek nincsenek érdekeltségeik.

\section{Köszönetnyilvánítás}

Köszönetünket fejezzük ki mindazoknak, akik véleményezték a kérdőív első változatát, kitöltötték a kérdőívet, és segítettek az adatfelvétel megszervezésében. Külön köszönet illeti Kormos-Krakkó Ágnest a fordításban, dr. Bárdos Helgát a Newest Vital Sign kérdőív tápanyagcím kéjének kialakításában való közremúködésért, $d r$. Kósa Karolinát a tanácsaiért, valamint Kun Esztert a Newest Vital Sign kérdőív Szinapszis Piackutató és Tanácsadó Kft. által fordított változatának átadásáért.

\section{Irodalom}

[1] Berkman ND, Sheridan SL, Donahue KE, et al. Low health literacy and health outcomes: an updated systematic review. Ann Intern Med. 2011; 155: 97-107.

[2] Vernon JA, Trujillo A, Rosenbaum S, et al. Low health literacy: implications for national health policies. 2007. Available from: https://publichealth.gwu.edu/departments/healthpolicy/ CHPR/downloads/LowHealthLiteracyReport10_4_07.pdf [accessed: February 10, 2021].

[3] Simonds SK. Health education as social policy. Health Educ Monogr. 1974; 2(1_Suppl): 1-10.

[4] Csizmadia P. Definitions of health literacy. [Az egészségműveltség definíciói.] Egészségfejlesztés 2016; 57: 41-44. [Hungarian]

[5] World Health Organization. Health promotion glossary. WHO, Geneva, 1998. Available from: http://www.who.int/healthpromotion/about/HPR\%20Glossary\%201998.pdf?ua=1 [accessed: August 6, 2020].

[6] Sørensen K, Van den Broucke S, Fullam J, et. al. Health literacy and public health: a systematic review and integration of definitions and models. BMC Public Health 2012; 12: 80.

[7] Haun JN, Valerio MA, McCormack LA, et al. Health literacy measurement: an inventory and descriptive summary of 51 instruments. J Health Commun. 2014; 19(Suppl 2): 302-333.

[8] Papp-Zipernovszky O, Náfrádi L, Schulz JP, et al. "So each patient comprehends": measuring health literacy in Hungary. [„Hogy minden beteg megértse!” - Az egészségmúveltség (health literacy) mérése Magyarországon.] Orv Hetil. 2016; 157: 905-915. [Hungarian]

[9] Náfrádi L, Papp-Zipernovszky O, Schulz PJ, et al. Measuring functional health literacy in Hungary: validation of S-TOFHLA and chew screening questions. Cent Eur J Public Health 2019; 27: 320-325

[10] Koltai JA, Kun E. The practical measurement of health literacy in Hungary and in international comparison. [Az egészségértés gyakorlati mérése Magyarországon és nemzetközi összehasonlításban.] Orv Hetil. 2016; 157: 2002-2006. [Hungarian]

[11] Koltai JA, Kun E. Hungarian health literacy in international comparison. [A magyarországi egészségértés nemzetközi összehasonlításban.] Egészségfejlesztés 2016; 57: 3-20. [Hungarian]

[12] Chew LD, Bradley KA, Boyko EJ. Brief questions to identify patients with inadequate health literacy. Fam Med. 2004; 36: $588-594$.

[13] Haun J, Noland Dodd VJ, Graham-Pole J, et al. Testing a health literacy screening tool: implications for utilization of a BRIEF health literacy indicator. Fed Pract. 2009; 26: 24.

[14] Haun J, Luther S, Dodd V, et al. Measurement variation across health literacy assessments: implications for assessment selection in research and practice. J Health Commun. 2012; 17(Suppl 3): 141-159.

[15] Weiss BD, Mays MZ, Martz W, et al. Quick assessment of literacy in primary care: the Newest Vital Sign. Ann Fam Med. 2005; 3: 514-522.

[16] Duell P, Wright D, Renzaho AM, et al. Optimal health literacy measurement for the clinical setting: a systematic review. Patient Educ Couns. 2015; 98: 1295-1307.

[17] Rowlands G, Khazaezadeh N, Oteng-Ntim E, et al. Development and validation of a measure of health literacy in the UK: the Newest Vital Sign. BMC Public Health 2013; 13: 116.

[18] Weiss BD. The Newest Vital Sign: frequently asked questions. Health Lit Res Pract. 2018; 2: el25-e127.

[19] Terwee CB, Bot SD, de Boer MR, et al. Quality criteria were proposed for measurement properties of health status questionnaires. J Clin Epidemiol. 2007; 60: 34-42. 
[20] Thorndike RL. Reliability. In: Lindquist EF. (ed.) Educational measurement. 2nd edn. American Council on Education, Washington, DC, 1971; pp. 560-620.

[21] Hinkle DE, Wiersma W, Jurs SG. Applied statistics for the behavioral sciences. 5th edn. Houghton Mifflin, Boston, MA, 2003.

[22] Nunnally J, Bernstein I. Psychometric theory. 3rd edn. McGrawHill, New York, NY, 1994.

[23] Child D. Essentials of factor analysis. 3rd edn. Continuum, New York, NY, 2006

[24] Ozdemir H, Alper Z, Uncu Y, et al. Health literacy among adults: a study from Turkey. Health Educ Res. 2010; 25: 464477.

[25] Xue J, Liu Y, Sun K, et al. Validation of a newly adapted Chinese version of the Newest Vital Sign instrument. PLoS ONE 2018; 13: $\mathrm{e} 0190721$.

[26] Tseng HM, Liao SF, Wen YP, et al. Adaptation and validation of a measure of health literacy in Taiwan: the Newest Vital Sign. Biomed J. 2018; 41: 273-278.

[27] Rodrigues R, de Andrade S, González A, et al. Cross-cultural adaptation and validation of the Newest Vital Sign (NVS) health literacy instrument in general population and highly educated samples of Brazilian adults. Public Health Nutr. 2017; 20: 19071913.

[28] Kogure T, Sumitani M, Suka M, et al. Validity and reliability of the Japanese version of the Newest Vital Sign: a preliminary study. PLoS ONE 2014; 9: e94582.

[29] Martins AC, Andrade IM. Cross-cultural adaptation and validation of the Portuguese version of the Newest Vital Sign. Rev Enfermagem Ref. 2014; 4: 75-83.

[30] Pereira Cruvinel AF, Cusicanqui Méndez DA, Campos Chaves $\mathrm{G}$, et al. The Brazilian validation of a health literacy instrument: the newest vital sign. Acta Odontol Scand. 2018; 76: 587-594.

[31] Huang YM, Shiyanbola OO, Smith PD, et al. Quick screen of patients' numeracy and document literacy skills: the factor structure of the Newest Vital Sign. Patient Prefer Adherence 2018; 12: 853-859

\section{PÁLYÁZATI FELHÍVÁS}

\section{Gyöngyös Városi Önkormányzat pályázatot hirdet Felnőtt háziorvosi feladatok ellátására}

Gyöngyös városában a gyöngyösi I. számú felnött háziorvosi körzetben vállalkozási formában, határozatlan idöre szóló feladatellátási szerződés keretében heti 40 órában, a felnőtt háziorvosi feladatok ellátásához kapcsolódó ügyeleti ellátásban történő részvétel vállalásával, a Nemzeti Egészségbiztositási Alapkezelő által kötött szerződés szerinti közvetlen finanszírozással, a Gyöngyös, Diósmalom u. 41. szám alatti háziorvosi rendelő és a rendelő tárgyi eszközeinek használatával.

A körzet 2019. február 1-töl tartósan betöltetlen háziorvosi körzetnek minősül, ezért külön támogatás igényelhetö a NEAK-tól.

\section{Pályázati feltételek:}

- 4/2000. (II. 25.) EüM rendeletben meghatározott képesités,

- 18/2000. (II. 25.) Korm. rendeletben elöirt egyéb feltételek megléte,

- részletes szakmai önéletrajz,

- végzettséget igazoló okmányok másolata,

- OONYI kárty másolata,

- érvényes MOK tagsági kártya megléte,

- 3 hónapnál nem régebbi erkölcsi bizonyítvány,

- hozzájárulás a pályázati anyag elbírálásában résztvevők betekintési jogához.

A pályázat benyújtásának határideje: az Orvosi Hetilapban történő felhivás megjelenésétől számított 30 nap.

A pályázat elbírálásának határideje: a benyújtási határidőt követő soros Képviselö-testületi ülés.

\section{A pályázat benyújtásának módja:}

- személyesen vagy postai úton Gyöngyös Városi Önkormányzat, Hiesz György polgármester részére (3200 Gyöngyös, Fö tér 13.) történő átadásával/megküldésével,

- a kizárólag elektronikus úton történő jelentkezés érvénytelennek minősül.

\section{A feladat ellátásának időpontja:}

a feladat legkorábban a Képviselö-testület döntését követő megegyezés szerint, de legkorábban 2021. november 1-töl látható el.

\section{További felvilágosítás kérhető:}

Gyöngyösi Közös Önkormányzati Hivatal Közigazgatási és Intézményirányitási Igazgatóság: dr. Horváth Gábor igazgatótól a 06-37/510-329 telefonon vagy személyesen előzetes időpont-egyeztetést követően. 